\title{
RHEOLOGICAL PROPERTIES OF LACTOSE-FREE YOGHURT IN RELATION TO ENZYME CONCENTRATIONS
}

\author{
Jamshidbek Khabibullaev $^{1^{*}}$, Jelena Zagorska ${ }^{1}$, Ruta Galoburda ${ }^{1}$, Ingmars Cinkmanis ${ }^{2}$ \\ ${ }^{1}$ Department of Food Technology, Faculty of Food Technology, Latvia University of Life Sciences and Technologies, \\ Rigas iela 22, Jelgava, Latvia, e-mail: jamshidziyo27@mail.ru \\ ${ }^{2}$ Department of Chemistry, Faculty of Food Technology, Latvia University of Life Sciences and Technologies,
} Liela iela 2, Jelgava, Latvia

\begin{abstract}
Lactose-free yoghurt is one of the main sources of useful nutrients for people who have got lactose intolerance. Therefore preparing lactose-free yoghurt is considered as an actual issue in the Republic of Uzbekistan. Many factors can affect the rheological and textural parameters of lactose-free yoghurt, including enzyme concentration, which is used to convert lactose in glucose and galactose. The aim of the study was to evaluate enzyme concentration influence on the rheological properties of lactose-free yoghurt. Yoghurt samples were made from pasteurized milk (fat content 2.5\%, Tukuma piens Ltd., Latvia) using commercial frozen yoghurt starter culture FD-DVS YC-X11 (Danisco Ltd., Denmark) containing Lactobacillus delbrueckii ssp. bulgaricus and Streptococcus thermophilus strains, and different concentrations of enzyme NOLA ${ }^{\mathrm{TM}}$ Fit 5500 (Chr Hansen JSC., Denmark) - 0; 500; $1000 ; 1500$ and $2000 \mathrm{BLU} \mathrm{L}^{-1}$. Milk was pasteurized $\left(95 \pm 1{ }^{\circ} \mathrm{C}, 5 \mathrm{~min}\right)$, cooled down $\left(40 \pm 1{ }^{\circ} \mathrm{C}\right)$, inoculated with starter and enzyme, mixed and fermented till $\mathrm{pH} 4.8 \pm 0.1$ then samples were mixed and cooled down till $5 \pm 1{ }^{\circ} \mathrm{C}$. Textural properties and viscosity of yoghurt samples were analysed using texture analyser TA.HD Plus and DV-III Ultra Programmable Rheometer. Lactose, galactose, glucose contents were measured by HPLC (SHIMADZU, Prominence, USA). The textural properties (such as firmness, consistency, cohesiveness) and viscosity of analysed yoghurt samples were significantly $(\mathrm{p}<0.05)$ different for samples with higher enzyme concentration, which showed the lowest viscosity. Rheological properties denote a weaker network of yoghurt gel in samples with full lactose hydrolysis. Results from chromatography provided no lactose presence in any experimental sample with enzyme, the galactose was dominant monosaccharide in each sample treated with enzyme.
\end{abstract}

Keywords: lactose-free yoghurt, enzyme, viscosity, consistency

\section{Introduction}

Yoghurt is a dairy product produced by fermenting the milk using starter culture consisting of the mix of Lactobacillus bulgaricus and Streptococcus thermophilus (Wolf et al., 2015). Yoghurt contains naturally an expressive content of $\mathrm{Ca}$ and $\mathrm{K}$ and it is a source of high quality protein, providing satiety and promoting muscle growth and bone health (Souza et al., 2018). Apart from this, daily intake of yoghurt is usually associated with beneficial health effect such as protection against cancer, enhancement of immune response and cholesterol reduction in the blood (Wolf et al., 2015). However, not all people can consume dairy products including yoghurt because of the high lactose content $(3.5-3.7 \%)$. Lactose is a disaccharide presented in all type of milk with different quantities. It is hydrolysed by the intestinal brush-border enzyme, lactase, into absorbable sugars, namely glucose and galactose. People with disability of digestion of lactose due to the lack of enzyme - $\beta$-galactosidase in small intestines are called lactose intolerant. More than $70 \%$ of the world population suffers from lactose intolerance (Schmidt et al., 2017), but its occurrence largely depends on the population group: only approx. $10 \%$ of Northern Europeans but more than $90 \%$ of South-East Asians suffer from lactose intolerance (Jelen, Tossavainen, 2003). For this reason, majority of the world population encounters problems due to their consumption of foods containing high amount of lactose. One of the strategies more assayed to obtain reduced-lactose yoghurts is the lactose hydrolysis by the enzymatic treatment (Mlichová, Rosenberg, 2006).
But, lactose-free yoghurt with good technical quality parameters is still not available on the markets of Uzbekistan. Recently, Kasimov et al. (2015) has performed experiment by testing gene variants of the Uzbek population from Andijan region. Despite of the fact that people suffering from lactose intolerance in the Republic of Uzbekistan is under $20 \%$, results showed that almost $81 \%$ of the volunteers participated in the experiment possess LNP C/C-13910 gene, which is characterized by a decrease in the level of lactase in adulthood. This means, producing yoghurt and dairy products with reduced lactose content and acceptable rheological properties is an actual task in the Republic of Uzbekistan.

$\beta$-galactosidase (lactase) is an enzyme that catalyses the hydrolysis of lactose to glucose and galactose. It can be isolated from plants, animals, yeasts, fungi and bacteria. It is potentially important in the production of lactosereduced products in the food and dairy industry for lactose intolerant populations (Souza et al., 2018). Since it is possible and preferable to perform lactose hydrolysis simultaneously with fermentation in order to save extra processing time, co-hydrolysis (starter and enzyme) used in production. This technological step, as well selection of enzyme concentration and starter can influence the rheological parameters of the product. However there is lack of information about lactose- free fermented products' rheological properties, which can be influenced by lactose enzymatic hydrolysis. The distinctive texture, mouth feeling and flavour make yoghurt an appealing product that takes a great portion in the dairy industry. 
The aim of the study was to evaluate enzyme concentration influence on the rheological properties of lactose-free yoghurt.

\section{Materials and Methods}

\section{Yoghurt preparation}

Pasteurized milk was bought from the local shop (fat content 2.5\%, Tukuma piens Ltd., Latvia). Initially, cow milk ( $\mathrm{pH} 6.70 \pm 0.05)$ was pasteurized $(95.0 \pm 1.0 \mathrm{C}$ for $5 \mathrm{~min}$ ), rapidly cooled till $40{ }^{\circ} \mathrm{C}$ and divided into five beakers (triplicate) in order to add different concentrations of enzyme (NOLA ${ }^{\mathrm{TM}}$ Fit 5500, Chr. Hansen Holding JSC, Denmark). Enzyme concentrations used in the research was: 0 (A - control sample), $500 \quad$ (B); $1000 \quad$ (C); $1500 \quad$ (D) and 2000 (E) BLU L-1, manufacturer recommended dose range from 500 to $18000 \mathrm{BLU} \mathrm{L}^{-1}$. Enzyme and commercial frozen starter culture FD-DVS YC-X11 (Danisco Ltd., Denmark; containing EPS producing cultures: Lactobacillus delbrueckii ssp. bulgaricus and Streptococcus thermophilus) were added at the same time for each sample. All beakers were incubated in a thermostat (Incubator IN55, Memmert, Germany) at $40 \pm 1{ }^{\circ} \mathrm{C}$ during $5.0 \pm 0.5$ hours until $\mathrm{pH}$ reached $4.8 \pm 0.1$. After that, samples were mixed and cooled down till $5 \pm 1{ }^{\circ} \mathrm{C}$. Then, beakers containing yoghurt were matured and stored at $5 \pm 1{ }^{\circ} \mathrm{C}$ for 24 hours before analysis.

\section{Rheological analysis}

Viscosity was measured using DV-III Ultra Programmable Rheometer (Brookfield Engineering Laboratories Inc., USA). Yoghurt after an overnight storage at $5{ }^{\circ} \mathrm{C}$ was transferred into the small sample holder. Rotation speed of the SC4-16 spindle was set at $10 \mathrm{~min}^{-1}$. Data was recorded in the Rheocalc V2.6.: Rheometer program $10 \mathrm{~s}$ after beginning of the spindle rotation. Viscosity was measured 5 times using fresh yoghurt sample each time.

The rheological measurements were performed on a rheometer MCR-302 (Anton Paar GmH, Austria) with cone-plate geometry $\left(50 \mathrm{~mm}, 1^{\circ}\right)$, gap $0.5 \mathrm{~mm}$ at $4.0 \pm 0.1^{\circ} \mathrm{C}$. The flow behaviour of yoghurt samples was evaluated by shear rate sweep after $30 \mathrm{~s}$ of pre-shear at $5 \mathrm{~s}^{-1}$ for equilibration. Then shear rate was increased from 0.1 to $200 \mathrm{~s}^{-1}$ in $300 \mathrm{~s}$ (for upward curve). Before downward curve a shearing for $60 \mathrm{~s}$ at $200 \mathrm{~s}^{-1}$ was performed. In the next interval, shear rate was decreased from 200 to $0.1 \mathrm{~s}^{-1}$ in another $300 \mathrm{~s}$. The flow curves were used to calculate thixotrophy area and yield point. In the oscillatory tests, storage (elastic) modulus $\mathrm{G}^{\prime}$ and loss (viscous) modulus $\mathrm{G}^{\prime \prime}$ were measured at frequencies between 0.1 and $100 \mathrm{~Hz}$, with a constant strain $1 \%$ within the linear viscoelastic region determined in preliminary amplitude test (strain $0.01-10 \%$, frequency $1 \mathrm{~Hz}$ ). The storage modulus, loss modulus and the tangent of the phase angle $(\tan \delta)$ at frequency $1 \mathrm{~Hz}$ were reported.

Textural analysis

TA.HD Plus (Stable Micro Systems, UK) was employed for texture properties of yoghurts, such as firmness, consistency, cohesiveness. A single compression test was performed using a back extrusion cell disc (A/BE; diameter $35 \mathrm{~mm}$; distance $30 \mathrm{~mm}$; pre-test speed $1.00 \mathrm{~mm} \mathrm{~s}^{-1}$; test speed $1.00 \mathrm{~mm} \mathrm{~s}^{-1}$; post-test speed $10.00 \mathrm{~mm} \mathrm{~s}^{-1}$; trigger force $0.098 \mathrm{~N}$ ) and extension bar with $50 \mathrm{~kg}$ load cell. All data were collected automatically on computer by Exponent 32 Software for further analysis.

\section{Microstructure characterization}

In order to learn and monitor the microstructure of yoghurt samples, the light microscope LEICA DM 3000 $L E D$ was applied. The microscope consisted of two lens with magnification $10 \times$ and $20 \times$ and was coupled with LEICA DFC290 HD camera to take digital pictures and save those in the computer. LAS V4.2 program of the computer was used to measure size of whey pockets on the surface of yoghurt samples from pictures.

\section{Chromatography analysis}

$10 \mathrm{~mL}$ of yoghurt samples transferred into named tubes and mixed with 4 drops of $\mathrm{CaCl}(5 \%)$. Then samples were heated till $95^{\circ} \mathrm{C}$ and poured through filter paper in order to split protein and obtain whey. To make the whey more transparent it was centrifuged (Centurion Scientific Limited - PrO-Research K243) for $10 \mathrm{~min}$, at $13000 \mathrm{rpm}$. The content of individual sugars - glucose, galactose and lactose was determined by a highperformance liquid chromatograph LC 20 Prominence (Shimadzu, Japan). Chromatographic parameters were set as follows: detector - refractive index RID-10A; column - Alltech NH2, $4.6 \mathrm{~mm} \times 250.0 \mathrm{~mm}, 5 \mu \mathrm{m}$; temperature $25{ }^{\circ} \mathrm{C}$; isocratic elution regime, mobile phase -A - acetonitrile, B - deionized water (A70 : B30); capacity of the injection sample $-10 \mu \mathrm{L}$; total time of the analysis - up to $15 \mathrm{~min}$; flow rate $1.0 \mathrm{~mL} \mathrm{~min}^{-1}$. Acquired data were processed using Shimadzu LabSolutions software (LCsolution Version 1.21 SP1).

\section{Data processing / Statistical analysis}

Analysis of variance (ANOVA) was done using Statistical 10.0 software (Stat Soft. Inc., Tulsa, USA) and the mean comparisons of parameters were performed by t-test, with the level of significance at 0.05 .

\section{Results and Discussion}

\section{Rheological properties of yoghurts}

The effect of lactose hydrolysis on the characteristics of the yoghurts during research was investigated. Significant differences $(\mathrm{p}<0.05)$ were detected regarding the viscosity results (see Fig. 1). The highest viscosity value was recorded for the control sample. Among the yoghurt samples hydrolysed by the enzyme showed consistent decrease as the amount of enzyme has increased in the samples. Viscosity of yoghurt samples were significantly different $(\mathrm{p}<0.05)$ from each other and depended on enzyme concentration.

All yoghurt samples presented a typical shear-thinning behaviour (Fig. 2) for the shear rates from 0.1 to 
$200 \mathrm{~s}^{-1}$. Flow curves of yoghurts showing shear stress versus shear rate clearly demonstrate hysteresis loops. It has been reported that high viscosity is related with bigger hysteresis area. In the present study hysteresis area decreased with the enzyme concentration, showing opposite trend to viscosity.

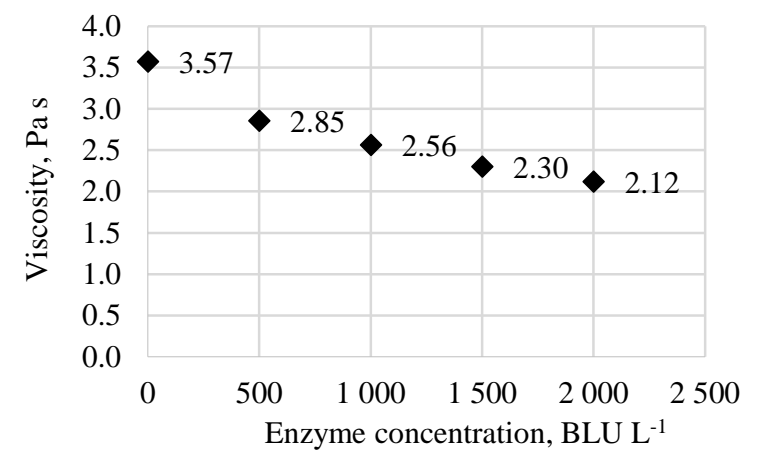

Figure 1. Yoghurt viscosity $(\mathrm{n}=5)$

The largest hysteresis area was found for the control and yoghurt with enzyme $500 \mathrm{BLU} \mathrm{L}^{-1}$. When enzyme was added to yoghurt its yield point was reduced, which can be associated to the changes in three-dimensional structures (Jaster et al., 2018).

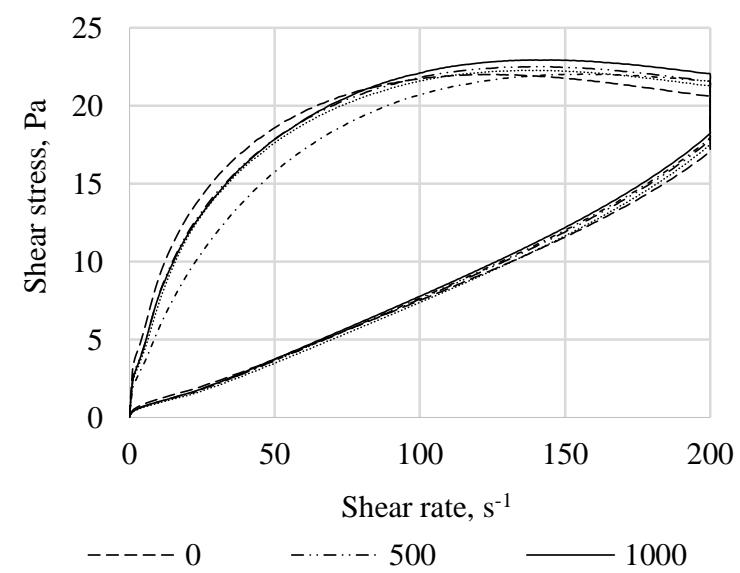

Figure 2. Flow curves of the yoghurt samples with different enzyme concentrations (0-2000 BLU $\left.\mathrm{L}^{-1}\right)$

All samples with added enzyme had lower values of yield point compared to control yoghurt (Table 1), which also denotes a weaker network of yoghurt gel.

Table 1

Rheological properties of yoghurts with different enzyme concentrations

\begin{tabular}{lll}
\hline $\begin{array}{l}\text { Enzyme } \\
\text { concentration, } \\
\text { BLU L } \mathbf{~}^{-1}\end{array}$ & $\begin{array}{c}\text { Hysteresis area, } \\
\text { kPa s }^{-1}\end{array}$ & Yield point, Pa \\
\hline 0 & $2.37 \pm 0.06^{\mathrm{a}}$ & $0.39 \pm 0.02^{\mathrm{a}}$ \\
500 & $2.32 \pm 0.08^{\mathrm{a}}$ & $0.16 \pm 0.08^{\mathrm{b}}$ \\
1000 & $2.23 \pm 0.05^{\mathrm{b}}$ & $0.14 \pm 0.10^{\mathrm{bc}}$ \\
1500 & $2.20 \pm 0.09^{\mathrm{b}}$ & $0.11 \pm 0.09^{\mathrm{c}}$ \\
2000 & $2.06 \pm 0.10^{\mathrm{c}}$ & $0.17 \pm 0.02^{\mathrm{b}}$ \\
\hline
\end{tabular}

$(n=3)$; values with different superscripts within the same column are significantly different $(\mathrm{P}<0.05)$.
The apparent viscosity decreased with increasing shear rate (Fig. 3), which also showed that yoghurt was pseudoplastic. This shear-thinning behaviour may be attributed to the destroying weak bonds formed in yoghurt gels (Cui et al., 2014) and reduce hydrophobic interactions between molecules. This disruption is greater in the beginning of the process. The viscosity profiles for the samples almost overlapped at the most shear rates, except sample made with the enzyme concentration $2000 \mathrm{BLU} \mathrm{L}^{-1}$, which exhibited lower apparent viscosity.

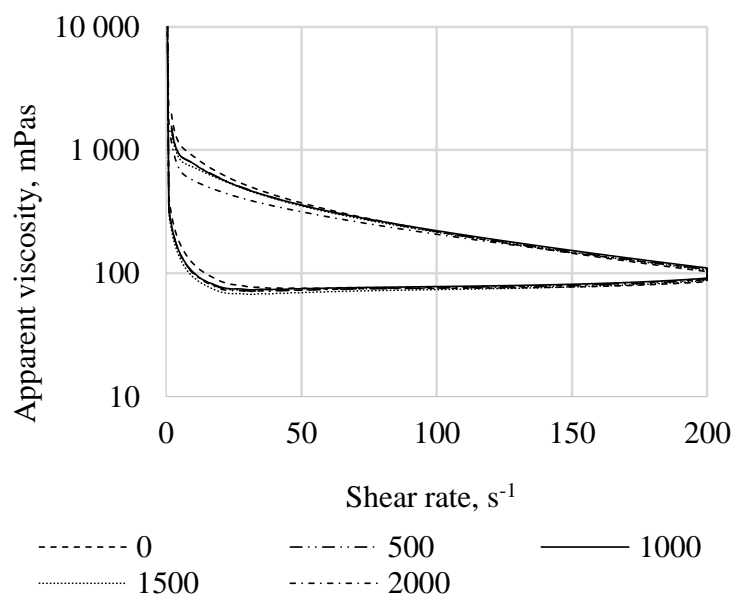

Figure 3 Viscosity curves of the yoghurt samples with different enzyme concentrations $\left(0-2000 B L U \mathrm{~L}^{-1}\right)$

Table 2 shows the storage modulus $\left(\mathrm{G}^{\prime}\right)$, loss modulus $\left(\mathrm{G}^{\prime \prime}\right)$ and loss tangent $\left(\tan \delta=\mathrm{G}^{\prime \prime} / \mathrm{G}^{\prime}\right)$ of the yoghurt samples with different enzyme concentrations. The lowest $\tan \delta$ value of control sample indicate that the sample is more solid-like compared to the samples with enzyme additive.

Table 2

Viscoelastic properties of yoghurts with different enzyme concentrations from frequency sweeps (at $1 \mathrm{~Hz}$ )

\begin{tabular}{llll}
\hline $\begin{array}{l}\text { Enzyme } \\
\text { concentration, } \\
\text { BLU L }{ }^{-1}\end{array}$ & $\begin{array}{c}\text { Storage } \\
\text { modulus } \\
\mathbf{G}^{\prime}, \mathbf{P a}\end{array}$ & $\begin{array}{c}\text { Loss } \\
\text { modulus } \\
\mathbf{G}^{\prime \prime}, \mathbf{P a}\end{array}$ & $\begin{array}{c}\text { Loss factor } \\
\tan \boldsymbol{\delta}\end{array}$ \\
\hline 0 & $12.07^{\mathrm{a}}$ & $3.38^{\mathrm{a}}$ & $0.281^{\mathrm{d}}$ \\
500 & $10.93^{\mathrm{ab}}$ & $3.17^{\mathrm{b}}$ & $0.291^{\mathrm{cb}}$ \\
1000 & $11.27^{\mathrm{a}}$ & $3.19^{\mathrm{b}}$ & $0.284^{\mathrm{d}}$ \\
1500 & $9.29^{\mathrm{b}}$ & $3.12^{\mathrm{b}}$ & $0.338^{\mathrm{a}}$ \\
2000 & $7.87^{\mathrm{c}}$ & $2.43^{\mathrm{c}}$ & $0.318^{\mathrm{b}}$ \\
\hline
\end{tabular}

$(\mathrm{n}=3)$; values with different superscripts within the same column are significantly different $(\mathrm{p}<0.05)$

Small amplitude oscillatory tests revealed the decrease of storage modulus $\mathrm{G}^{\prime}$ with the enzyme concentration. The $\mathrm{G}^{\prime}$ values ranged between 7.87 and $12.07 \mathrm{~Pa}$, with lower values for samples with higher enzyme concentration, indicating formation of weaker gel comparing to control sample or sample with 
$500 \mathrm{BLU} \mathrm{L}^{-1}$ enzyme. Similar trend was observed for loss modulus $\mathrm{G}^{\prime \prime}$.

\section{Textural properties of yoghurts}

Textural properties of yoghurts samples are presented in the Table 3. A highly significant firmness, consistency and cohesiveness were found for the control sample making standard sample significantly different from the other samples and reduced viscosity with the increased amount of enzyme for rest of the samples. Despite of the fact that textural results showed the tendency of decrease in relation to the enzyme concentration, statistical test provided no difference among the samples of 500, 1000 and $1500 \mathrm{BLU} \mathrm{L}^{-1}$. Significant differences were detected between samples of the smallest and the highest concentrations regarding to the firmness, consistency and cohesiveness. There are several factors, which can directly affect the rheological properties of the yoghurt. For example, lipid content and globule size are important factors affecting the gel firmness. However, looking at our results from rheological studies, it was clear that lactose hydrolysis had a significant influence on the texture and viscosity of yoghurts.

Changes of lactose free yoghurt rheological properties can be explained by lactose enzymatic hydrolysis, changing rate of glucose and galactose (Table 4) consumed by starter cultures and differences in the production of derived compounds (Goff, 2002).

Table 4

Sugar profile in yoghurt samples

\begin{tabular}{lccc}
\hline $\begin{array}{l}\text { Enzyme } \\
\text { concentration, } \\
\text { BLU L } \mathbf{~}^{-1}\end{array}$ & $\begin{array}{c}\text { Glucose, } \\
\mathbf{g ~ L}^{-1}\end{array}$ & $\begin{array}{c}\text { Galactose, } \\
\mathbf{g ~ L}^{-1}\end{array}$ & $\begin{array}{c}\text { Lactose, } \\
\mathbf{g ~ ~ ^ { - 1 }}\end{array}$ \\
\hline 0 & 0.612 & 6.942 & 33.425 \\
500 & 18.441 & 23.924 & 0.000 \\
1000 & 19.419 & 27.202 & 0.000 \\
1500 & 19.704 & 25.685 & 0.000 \\
2000 & 18.977 & 26.436 & 0.000 \\
\hline
\end{tabular}

It is supposed, that the concentration of exopolysaccharide was assumed high on the sample, where less enzyme was added corresponding to the higher firmness, higher cohesiveness, higher consistency and higher viscosity, respectively. It was also reported that the exopolysaccharide could improve the texture of yoghurt, still exopolysaccharide produced by $\mathrm{LAB}$ interacts with the free water in the gel-like structure (Han et al., 2016). In this study control sample and yoghurt hydrolysed with less amount of commercial enzyme showed higher viscosity and texture behaviour comparing to other samples.

Table 3

Textural properties of yoghurt samples

\begin{tabular}{llll}
\hline $\begin{array}{l}\text { Enzyme concentration, } \\
\text { BLU L }\end{array}$ & Firmness, g & Consistency, g s & Cohesiveness, $\mathbf{g}$ \\
\hline 0 & $66.42 \pm 5.05^{\mathrm{a}}$ & $1753.96 \pm 162.86^{\mathrm{a}}$ & $-66.34 \pm 5.29^{\mathrm{a}}$ \\
500 & $55.69 \pm 3.35^{\mathrm{bcd}}$ & $1453.86 \pm 6.30^{\mathrm{bcd}}$ & $-59.16 \pm 7.86^{\mathrm{bcde}}$ \\
1000 & $55.36 \pm 2.67^{\mathrm{cde}}$ & $1453.71 \pm 70.75^{\text {cde }}$ & $-56.02 \pm 6.64^{\text {cde }}$ \\
1500 & $54.04 \pm 3.95^{\mathrm{de}}$ & $1423.88 \pm 110.61^{\mathrm{de}}$ & $-55.53 \pm 5.03^{\mathrm{de}}$ \\
2000 & $53.13 \pm 3.33^{\mathrm{e}}$ & $1388.13 \pm 82.61^{\mathrm{e}}$ & $-53.88 \pm 3.37^{\mathrm{e}}$ \\
\hline
\end{tabular}

$(\mathrm{n}=5)$; values with different superscripts within the same column are significantly different $(\mathrm{p}<0.05)$
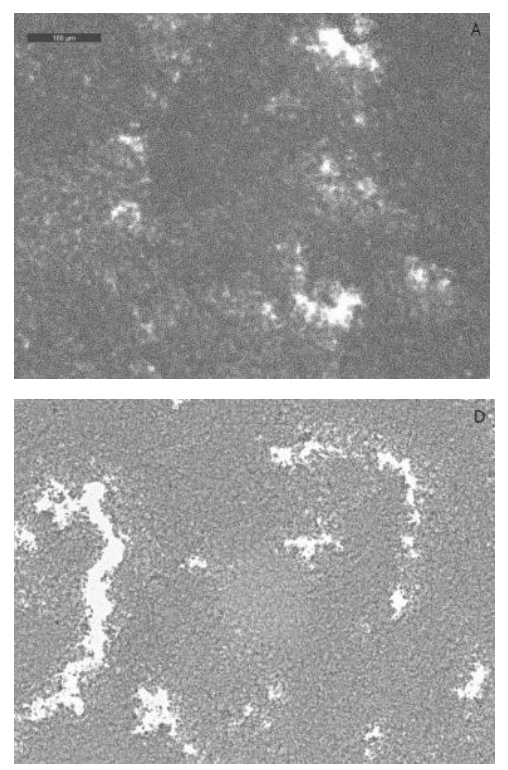
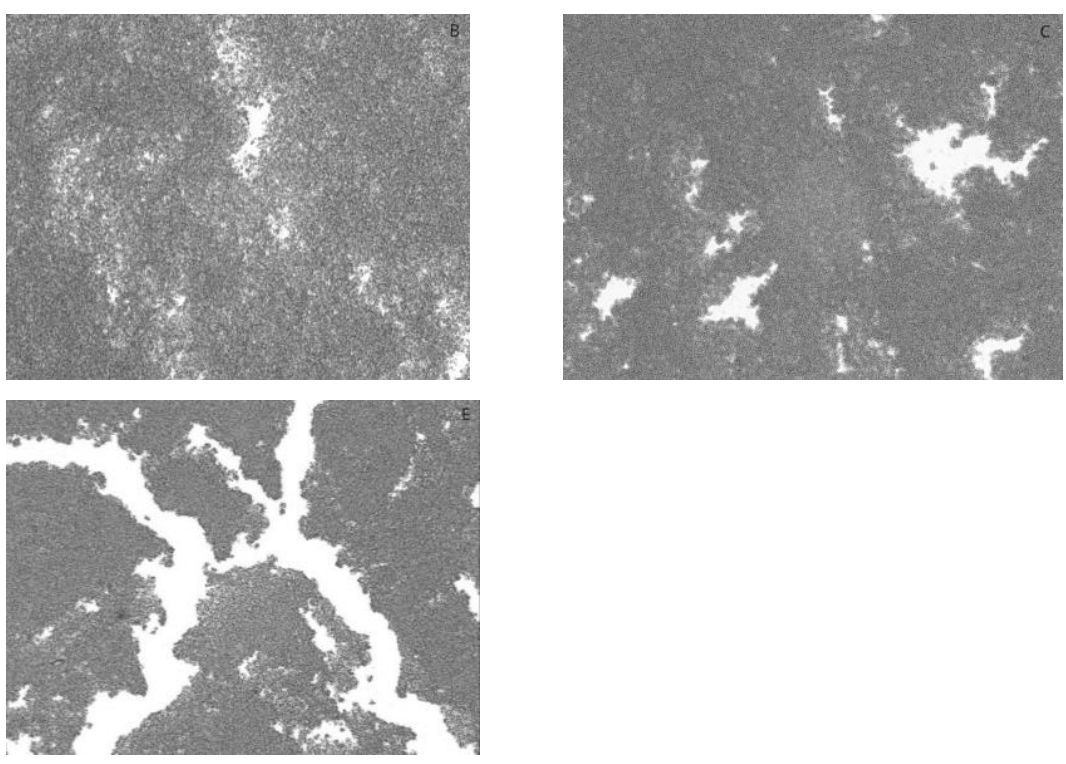

Figure 4. Microscopic images of yoghurt samples

A - control sample; B - $500 \mathrm{BLU} \mathrm{L}{ }^{-1}$; C - $1000 \mathrm{BLU} \mathrm{L}^{-1}$; D - $1500 \mathrm{BLU} \mathrm{L}^{-1}$; E - $1500 \mathrm{BLU} \mathrm{L}^{-1}$ (all images under $100 \mu \mathrm{m}$ ) 
The possible explanation of obtained results was the activity of other enzymes incorporated in NOLA ${ }^{\mathrm{TM}}$ Fit 5500. According to the information obtained from the literature cellulases and proteases have been used for more efficient dispersion and extraction of proteins, particularly after heat treatment, used in yogurt production, making them denaturated (Aguilera, Stanley, 1999).

\section{Microstructure of yoghurts}

The results from the microstructural analyses of yoghurts are presented in Fig. 4. The microstructural observations showed that sample with less enzyme had smaller whey pockets rather than those with higher concentration of enzyme. Similar results had also been reported by other studies (Ibrahim, 2018; Schmidt et al, 2017). This might be due to the high water-binding capacity of EPS as well as modifications of yoghurt microstructure by EPS culture. Thus, the yoghurts made from EPS producing starters showed better textural characteristics. Furthermore, yoghurt cultures producing EPS may decrease the extent of syneresis (the lower whey separation). Syneresis is considered as a major defect in yoghurt and connected with extensive rearrangements of the gel network (Han et al., 2016). Whey pockets became wider depending on the enzyme concentration used on each sample due to the reason mentioned above.

According to the measurements, size of the whey pocked also increased: control sample (248 $\left.\mu \mathrm{m}^{2}\right)$; $500 \mathrm{BLU} \mathrm{L} \mathrm{L}^{-1}\left(642 \mu \mathrm{m}^{2}\right) ; 1000 \mathrm{BLU} \mathrm{L}^{-1}$ $\left(2640 \mu \mathrm{m}^{2}\right) ; 1500 \mathrm{BLU} \mathrm{L}^{-1}\left(4004 \mu \mathrm{m}^{2}\right) ; 2000 \mathrm{BLU} \mathrm{L}^{-1}$ $\left(101494 \mu \mathrm{m}^{2}\right)$. Sugar profile and concentrations in yoghurt samples are given in Table 4. Results from chromatography analysis provided no lactose presence in any sample with enzyme, the galactose was dominant monosaccharide in each sample treated with enzyme.

Complete lactose conversion to galactose and glucose in each sample (B, C, D, E) with NOLA $^{\mathrm{TM}}$ Fit 5500 enzyme was detected in the research.

In order to achieve the highest conversion of lactose with less amount of commercial enzyme is beneficial from financial side.

\section{Conclusions}

Rheological properties of lactose-free yoghurt significantly depend on enzyme concentration used for lactose hydrolysis, reflected in a significantly lower viscosity, firmness, consistency, but higher size of whey pockets in yoghurt samples with increased amount of enzyme comparing to the control sample. Results show that rheological properties of the yoghurt strongly depend on the lactose hydrolysis level.

For obtaining lactose free yoghurt with acceptable rheological properties the lowest concentration of $\beta$-galactosidase (500 BLU L${ }^{-1}$ ) is recommended.

\section{Acknowledgment}

The authors wish to acknowledge "El-Yurt Umidi" foundation under the Cabinet of Ministers of the Republic of Uzbekistan for providing the financial support for Jamshidbek Khabibullaev studies in Latvia University of Life Sciences and Technologies.

\section{References}

1. Aguilera J., M., Stanley D.W., (1999) Microstructure and mass transfer: Solid-liquid extraction, In: Microstructural Principles of Food Processing and Engineering. $2^{\text {nd }}$ ed. Aguilera J., M., Stanley D.W. (eds). Gaithersburg, Maryland, AN Aspen Publication, p. 325-340.

2. Cui B., Lu Y.M., Tan C.P., Wang G.Q., Li G.H. (2014) Effect of cross-linked acetylated starch content on the structure and stability of set yoghurt. Food Hydrocolloids, Vol. 35, p. 576-582.

3. Goff H.D. (2002) Formation and stabilisation of structure in ice-cream and related products. Current Opinion in Colloid \& Interface Science, Vol. 7(5-6), p. 432-437.

4. Han X., Yang Z., Jing X., Yu P., Zhang Y., Yi H., Zhang L. (2016) Improvement of the texture of yogurt by use of exopolysaccharide producing lactic acid bacteria. BioMed Research International, Vol. 2016, p. 1-6.

5. Ibrahim A.H. (2018) Impact of hydrolyzed lactose by $\beta$-galactosidase enzyme on the physicochemical and organoleptic properties of fermented camel milk. Emirate Journal of Food and Agriculture, Vol. 30(9), p. 778-790.

6. Jaster H., Arend G. D., Rezzadori K., Chaves V. C., Flávio Reginatto H., Cunha Petrus J. C. (2018) Enhancement of antioxidant activity and physicochemical properties of yogurt enriched with concentrated strawberry pulp obtained by block freeze concentration. Food Research International, Vol. 104, p. 119-125.

7. Jelen P., Tossavainen O. (2003) Low lactose and lactosefree milk and dairy products - Prospects, technologies and applications. Australian Journal of Dairy Technology, Vol. 58(2), p. 161-165.

8. Kasimov S., Nazarova G., Kasimova D., Yunusova Z., Rakhmatova M. (2015) A single nucleotide polymorphism C/T - 13910 and consumption of dairy products in Uzbek population. Journal of Evolution of Medical and Dental Sciences, Vol. 4(86), p. 15042-15050.

9. Mlichová Z., Rosenberg M. (2006) Current trends of $\beta$-galactosidase application in food technology. Journal of Food and Nutrition Research, Vol 45(2), p. 47-54.

10. Schmidt C., Mende S., Jaros D., Rohm H. (2017) Fermented milk products: effects of lactose hydrolysis and fermentation conditions on the rheological properties. Dairy Science and Technology, Vol. 96(2), p. 199-211.

11. Souza S.O., Santos V.S., Santos E.S., Ávila D.V.L., Nascimento C.C., Costa S.S.L., Garcia A.B., Araujo R.G.O. (2018) Evaluation of the mineral content in milk and yogurt types using chemometric tools. Microchemical Journal, Vol. 143, p. 1-8.

12. Wolf I.V., Vénica C.I., Perotti M.C. (2015) Effect of reduction of lactose in yogurts by addition of $\beta$-galactosidase enzyme on volatile compound profile and quality parameters. International Journal of Food Science and Technology, Vol 50(5), p. 1076-1082. 